\title{
Research on Trends in Extreme Weather Conditions and their Effects on Grapevine in Romanian Viticulture
}

\author{
Georgeta Mihaela BUCUR ${ }^{1 *}$, Anca Cristina BABEŞ² \\ ${ }^{1}$ Department of Horticultural bioengineering systems, University of Agronomic Sciences and Veterinary \\ Medicine, Bucharest, Romania, \\ ${ }^{2}$ Department of Horticulture and Landscape, University of Agricultural Sciences and Veterinary \\ Medicine, Cluj-Napoca, Romania. \\ *)Corresponding author, e-mail: mihaela_g_savu@yahoo.com
}

BulletinUASVM Horticulture 73(2) / 2016

Print ISSN 1843-5254, Electronic ISSN 1843-5394

DOI:10.15835/buasvmcn-hort:12190

\begin{abstract}
The aim of this work was to investigate the frequency and intensity of extreme weather events in various centers from viticultural regions from Romania: winter frost, extreme temperatures during the growing season and summer droughts. Winter frost damaging the vine is a significant risk to grape production, mainly in the plains and lowlands to the foothills. The frequency of winter frost damaging the vine has increased during the last decades, in the context of climate change. Also, there has been found a significant increase in the number of hot days $\left(\mathrm{T}_{\max }>30^{\circ} \mathrm{C}\right)$ and very hot days $\left(\mathrm{T}_{\max }>35^{\circ} \mathrm{C}\right)$. The evolution of these extreme events was followed in Craiova, Constanta, Bucharest, Timisoara, Cluj-Napoca, Oradea and Iasi, between 1977 and 2015. The long term study (18 years) conducted in the experimental plantation of the University of Agronomic Sciences and Veterinary Medicine Bucharest revealed their influence on vine. During the last two decades, there has been registered a trend of increasing the frequency and intensity of winter frost, damaging vine $\left(\mathrm{T}_{\min }<-20^{\circ} \mathrm{C}\right.$ ), heat waves (number of days with $\mathrm{T}_{\max }>30^{\circ} \mathrm{C}$ and $>35^{\circ} \mathrm{C}$ ) and droughts that adversely affect viticulture, production and quality of grapes and wine. The highest warming trends were observed in the northern viticultural regions (Transylvania and Moldavia) and in the coastal areas. Although the intensification of heat waves increases sugar accumulation in the berries, they trigger a significant reduction in grape production and in titratable acidity, requiring corrections and resulting in unbalanced wines. Meanwhile, droughts trigger production decrease. To avoid negative effects on vine, it is necessary to take measures, on a short, medium and long term.
\end{abstract}

Keywords: climate changes, extreme events, vine

\section{INTRODUCTION}

Romanian viticulture, influenced by temperate continental climate, with cold winters and hot summers, is subjected to both positive and negative influences of climate change (Bucur and Dejeu, 2014; Mereanu, 2010).

In the last decades, there was noticed a higher frequency of extreme weather events: the absolute minimum temperature during the dormant period was lower than $-20^{\circ} \mathrm{C}$, damaging grapevines; maximum temperatures above $30^{\circ} \mathrm{C}$ (hot days) and $35^{\circ} \mathrm{C}$ (very hot days); summer droughts, etc. (Bucur and Dejeu, 2014; Irimia et al., 2012; Lung et al., 2012; Pascual et al., 2016).

Minimum temperatures in winter have an important significance in assessing suitability for viticulture to a certain area (Dressler and Oberhofer, 2015), in the appropriate choice of land for growing grapevines and varieties (Quamme et al., 2010; Hill, 2011; Dami and Ennahli, 2012; 
Tab. 1. Geographical coordinates of the studied centers

\begin{tabular}{ccccc}
\hline Crt. no. & Meteorological station & Latitude & Longitude & Altitude $(\mathrm{m})$ \\
\hline 1. & Craiova & $44.31 \mathrm{~N}$ & $23.86 \mathrm{E}$ & 195 \\
\hline 2. & Constanta & $44.33 \mathrm{~N}$ & $28.43 \mathrm{E}$ & 25 \\
\hline 3. & Bucharest-Baneasa & $44.48 \mathrm{~N}$ & $26.11 \mathrm{E}$ & 91 \\
\hline 4. & Timisoara & $45.76 \mathrm{~N}$ & $21.25 \mathrm{E}$ & 88 \\
\hline 5. & Cluj-Napoca & $46.77 \mathrm{~N}$ & $23.60 \mathrm{E}$ & 335 \\
\hline 6. & Oradea & $47.03 \mathrm{~N}$ & $21.90 \mathrm{E}$ & 140 \\
\hline 7. & Iasi & $47.17 \mathrm{~N}$ & $27.63 \mathrm{E}$ & 104 \\
\hline
\end{tabular}

Tab. 2. Minimum temperatures below $-20^{\circ} \mathrm{C}$ recorded in BucharestBaneasa in the period 1991-2015 compared to the reference period 1961-1990

\begin{tabular}{cc}
\hline $\mathbf{1 9 9 1 - 2 0 1 5}$ & $\mathbf{1 9 6 1 - 1 9 9 0}$ \\
\hline 1997: $-20.0^{\circ} \mathrm{C}(18.12 .1997)$ & $1963:-23.7^{\circ} \mathrm{C}(18.01 .1963)$ \\
\hline 1998: $-20.3^{\circ} \mathrm{C}(25.12 .1998)$ & $1969:-21.7^{\circ} \mathrm{C}(05.02 .1969)$ \\
\hline $2002:-25.7^{\circ} \mathrm{C}(26.12 .2002)$ & $1980:-24.5^{\circ} \mathrm{C}(15.01 .1980)$ \\
\hline $2003:-20.0^{\circ} \mathrm{C}(14.02 .2003)$ & $1985:-24.6^{\circ} \mathrm{C}(14.02 .1985)$ \\
\hline $2004:-20.8^{\circ} \mathrm{C}(13.02 .2004)$ & $1987:-21.7^{\circ} \mathrm{C}(31.01 .1987)$ \\
\hline $2005:-23.7^{\circ} \mathrm{C}(08.02 .2005)$ & \\
\hline $2010:-24.6^{\circ} \mathrm{C}(26.01 .2010)$ & \\
\hline $2012:-24.3^{\circ} \mathrm{C}(29.01 .2012)$ & \\
\hline $2015:-20.8^{\circ} \mathrm{C}(08.01 .2015)$ & \\
\hline
\end{tabular}

Planchon et al., 2015; Bieli et al., 2015; Rayne and Forest, 2016).

In the last years researchers were interested in grapevine varieties with winter hardiness (Dejeu et al., 2005; Iliescu et al., 2009; Rotaru et al., 2010).

The objectives of this work were to study the frequency and intensity of extreme weather conditions (winter frosts, heat waves and drought) and their influences on the vine in seven centers located in the main wine regions of Romania.

\section{MATERIALS AND METHODS}

In the present work the already recorded meteorological data were used from seven stations situated in the main winegrowing regions of Romania (Craiova, Constanta, Bucharest-Baneasa, Timisoara, Cluj-Napoca, Oradea and Iasi), in a period of 39 years (1977-2015), presented in Tab. 1.

There were studied the following variables: absolute minimum temperature $\left(\mathrm{T}_{\min }<-20^{\circ} \mathrm{C}\right)$ during winter period, harmful for the grapevine; number of hot days in the growing season $\left(\mathrm{T}_{\max }>\right.$ $30^{\circ} \mathrm{C}$ ); number of very hot days $\left(\mathrm{T}_{\max }>35^{\circ} \mathrm{C}\right)$ and drought periods in the summer.

To investigate the influence of these extreme weather conditions on grapevine, data from a long-lasting experience conducted at University of Agronomic Sciences and Veterinary Medicine of Bucharest were used, during 1998 and 2015. The experimental plantation was established in 1994, with ?Feteasca regala ? cultivar, clone $21 \mathrm{Bl}$, grafted on Kober 5 BB, planted at distances of $2.2 / 1.2 \mathrm{~m}$ (3787 vines/ha), with spur pruning cordon and loading of 10 buds/sqm. Correlation coefficients were determined using EXCEL program.

\section{RESULTS AND DISCUSSION}

Extreme minimum temperatures were registered in most of Romania winegrowing regions, in 1985, 1987, 2005, 2010, 2012 and 2015 , resulting in substantial production loss.

Under these conditions, vines suffer losses of buds viability, canes, and even of the trunk, which may affect the grapevine survival. 
Tab. 3. Average minimum temperature in January recorded in 7 centers from Romania (1977-2015)

\begin{tabular}{ccc}
\hline $\begin{array}{c}\text { Crt. } \\
\text { no. }\end{array}$ & Centers & $\begin{array}{c}\text { Average minimum temperature in } \\
\text { January }(1977-2015)\end{array}$ \\
\hline 1 & Craiova & $-4.78^{\circ} \mathrm{C}$ \\
\hline 2 & Constanța & $-3.52^{\circ} \mathrm{C}$ \\
\hline 3 & Bucharest-Baneasa & $-5.33^{\circ} \mathrm{C}$ \\
\hline 4 & Timisoara & $-3.78^{\circ} \mathrm{C}$ \\
\hline 5 & Cluj-Napoca & $-6.26^{\circ} \mathrm{C}$ \\
\hline 6 & Oradea & $-4.04^{\circ} \mathrm{C}$ \\
\hline 7 & Iasi & $-6.00^{\circ} \mathrm{C}$ \\
\hline
\end{tabular}

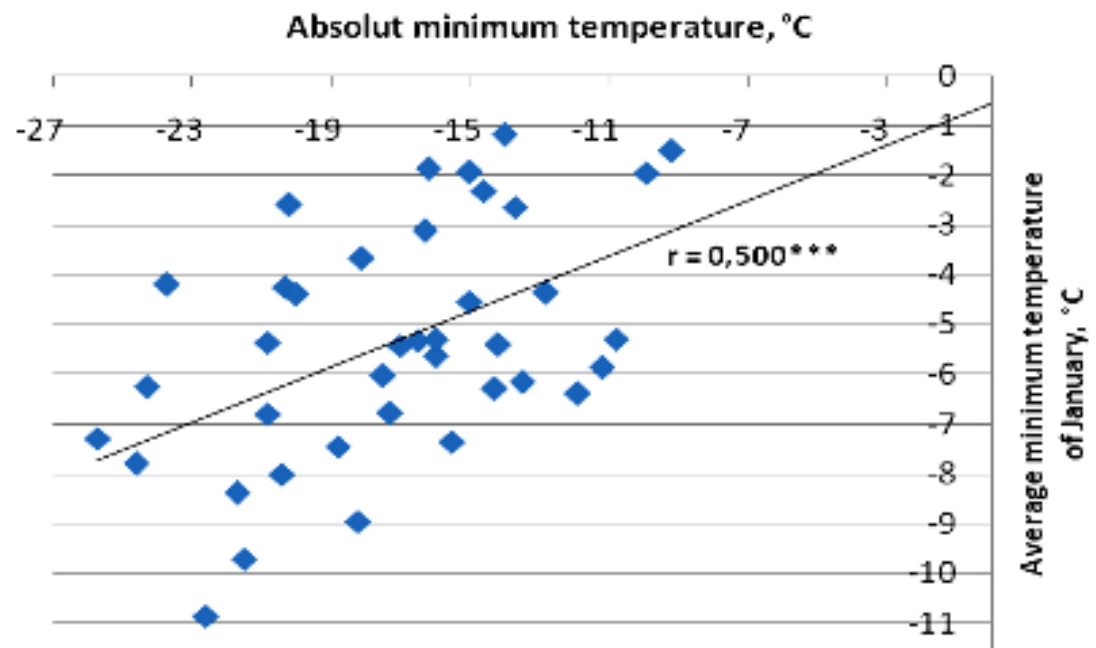

Fig. 1. Correlation between absolute minimum temperature and average minimum temperature in January (Bucharest- Baneasa, 1977-2015 )

Compared to the reference period (19611990) when there were 5 years with $\mathrm{T}_{\min }<-20^{\circ} \mathrm{C}$ (reoccurring 1.66 years out of 10 ), between 19912015 their frequency increased to 9 (reoccurring 3.6 years out of 10 ) (Tab. 2).

Bois et al. (2014) proved the effectiveness of the winter freeze risk index, appreciated based on average minimum temperatures in January. When the average minimum temperature of January has values higher than $4^{\circ} \mathrm{C}$ there is a low risk, but at values below $-11^{\circ} \mathrm{C}$, the risk of this phenomenon is very high.

Under our country conditions, this index ranges from $-3.57^{\circ} \mathrm{C}$ (Constanta) to $-6.26^{\circ} \mathrm{C}$ (ClujNapoca), indicating an average risk for winter freeze, higher in Transylvania and in North Eastern Romania (Tab. 3).

Fig. 1 shows the highly significant correlation between absolute minimum temperature and average minimum temperature in January for Bucharest-Baneasa. This correlation indicates that the average minimum temperature in January can be used to assess winter freeze risk.

Following the evolution of the absolute minimum temperatures in time for BucharestBaneasa and Iasi, a decrease of temperature can be observed (Fig. 2).

The absolute lowest minimum temperature of $-20^{\circ} \mathrm{C}$ reveals a drastic reduction in grape production (Fig. 3).

Heat waves were evaluated based on the number of days with $\mathrm{T}_{\text {max. }}>30^{\circ} \mathrm{C}$ and $>35^{\circ} \mathrm{C}$. The evolution of these indicators was highly significant for all the 7 studied centers (Fig. 4). The largest increase of the day number with $\mathrm{T}_{\text {max. }}>35^{\circ} \mathrm{C}$ was found in Craiova (+14 days) and the lowest in ClujNapoca ( +3 days). 

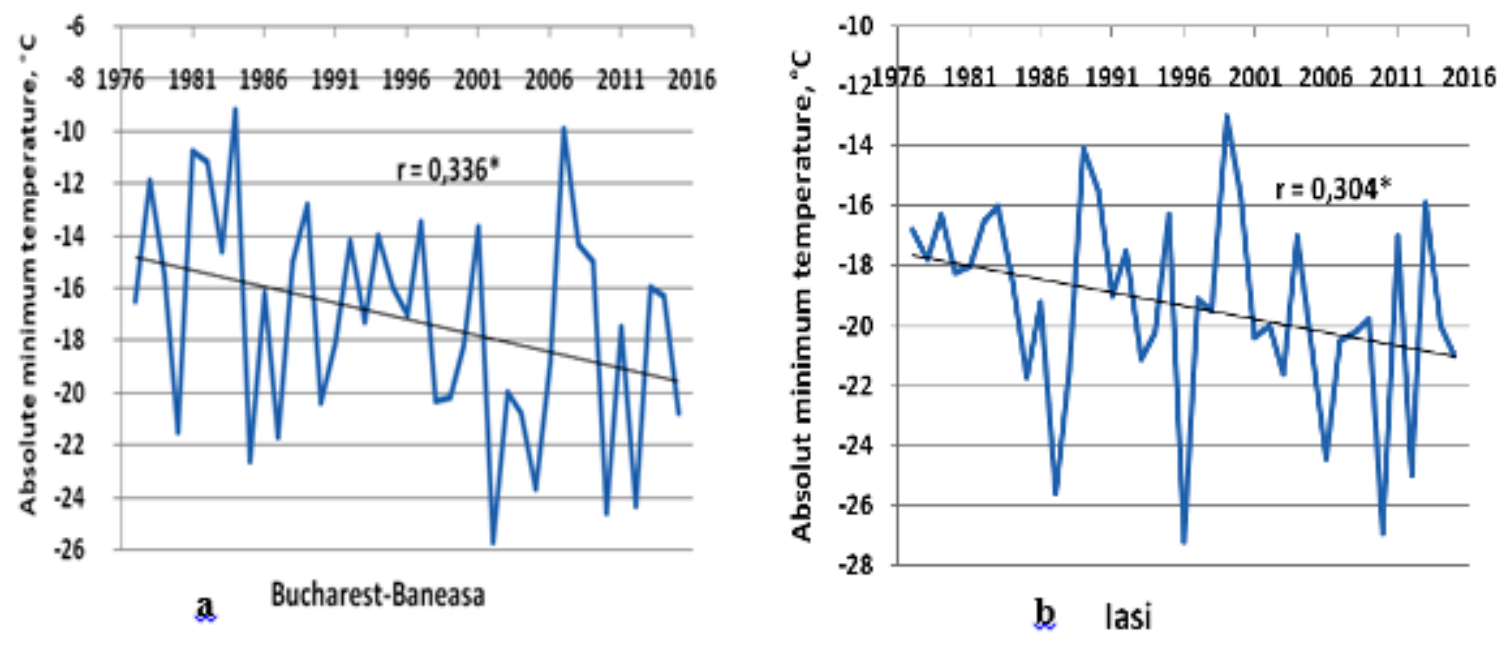

Fig. 2. Evolution of absolute minimum temperatures between 1977 and 2015: a - Bucharest; b - Iasi

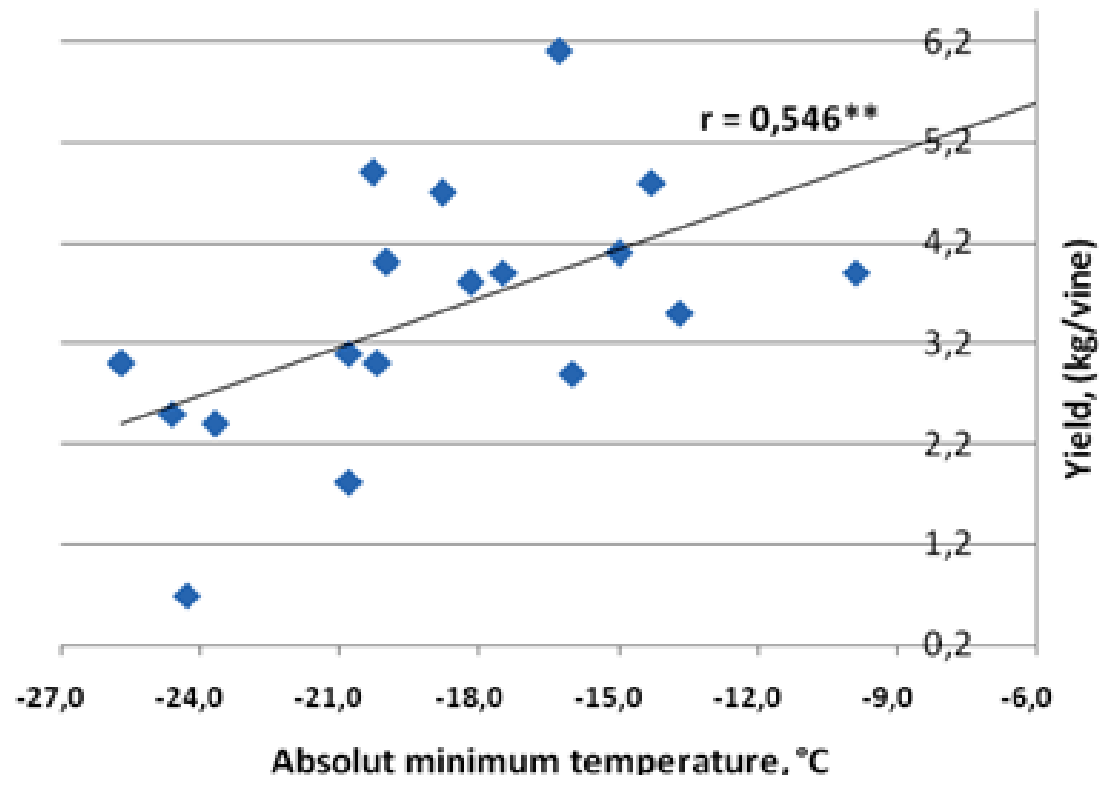

Fig. 3. Correlation between absolute minimum temperatures and grape production for ? Feteasca regala? cultivar (Bucharest-Baneasa, 1998-2015)

Fig. 5 shows a significant influence of the number of days with $\mathrm{T}_{\text {max. }}>35^{\circ} \mathrm{C}$ over the reduction of the grapes yield (a), in the average weight of the berry (b), in the concentration of sugars in the grapes (c) and the decrease in the titratable acidity of the must (d).

Under the weather conditions from Bucharest, the warmest year of the period studied was 2007 with an average annual temperature of $13.4^{\circ} \mathrm{C}$, compared to the annual average of $11.5^{\circ} \mathrm{C}$. Due to the extreme values of maximum temperatures during grapes ripening ( 4 consecutive days with $\mathrm{T}_{\max .}>40^{\circ} \mathrm{C}$ and intense solar radiation led to sunburned berries, especially after defoliation and on the west side of the row (Fig. 6).

In the summer the most pronounced droughts were recorded, during growing and ripening of the grape berries. In the studied period (19772015) the driest summers were in the 2000, 2012 (across all wine regions), followed by years: 1990, 1992 and 2003 (Tab. 4).

Under the pronounced drought conditions during the summers (Fig. 7) a higher accumulation of sugar (a), a drastic reduction of titratable acidity (b) were noticed as well as a decrease of grape yield (c). 

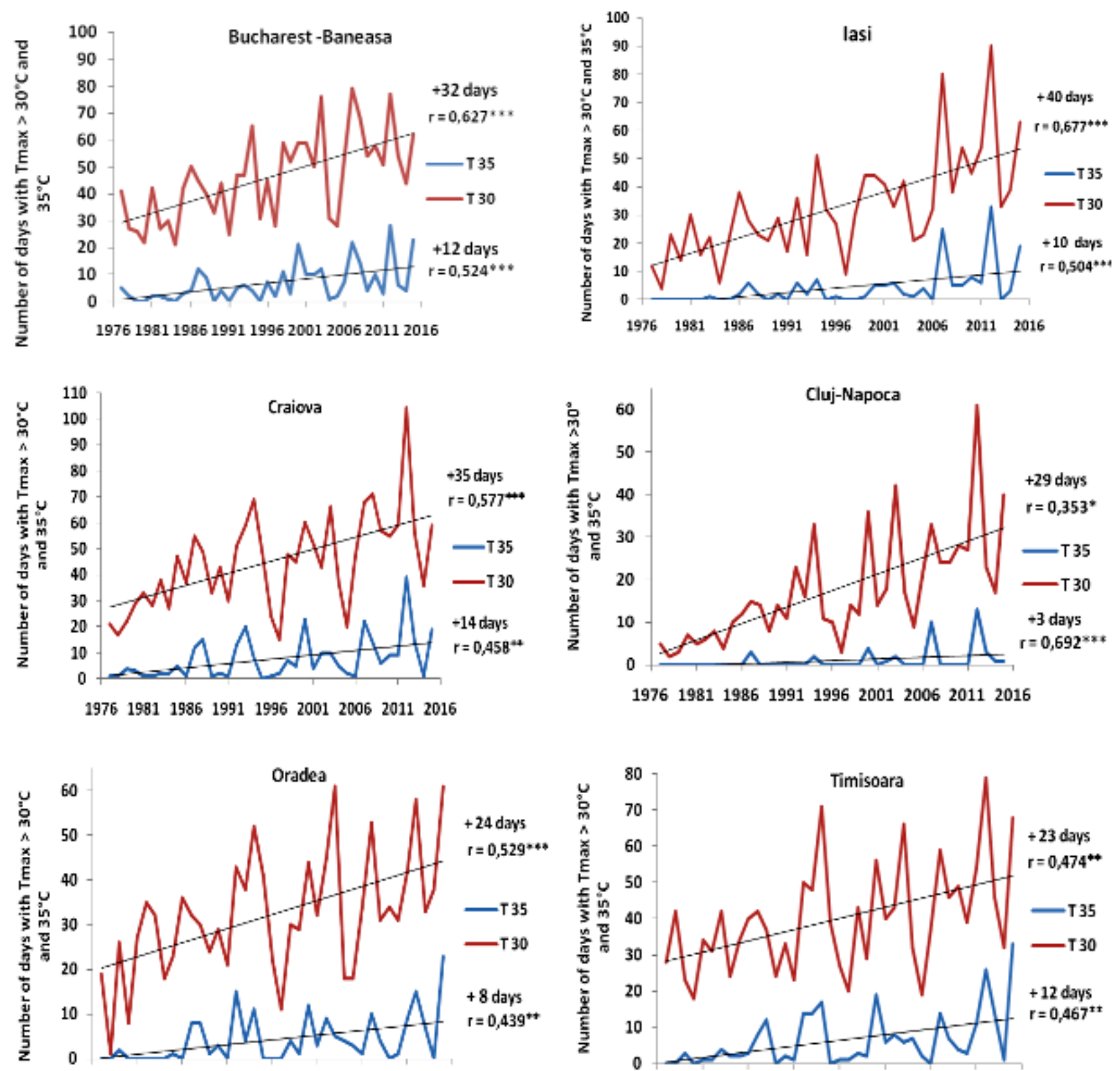

197619811986199119962001200620112016

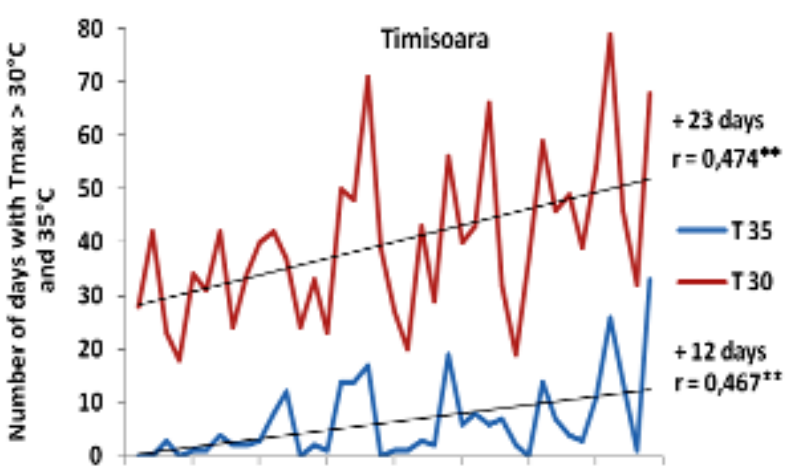

197619811986199119962001200620112016

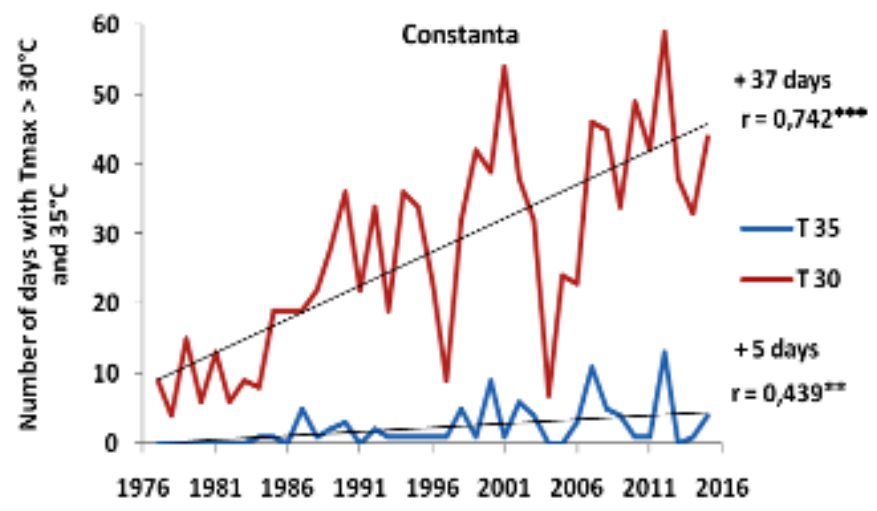

Fig. 4. Evolution of the number of days with $\mathrm{T}_{\text {max. }}>30^{\circ} \mathrm{C}$ and $35^{\circ} \mathrm{C}$ in the 7 centers, between $1977-2015$ 

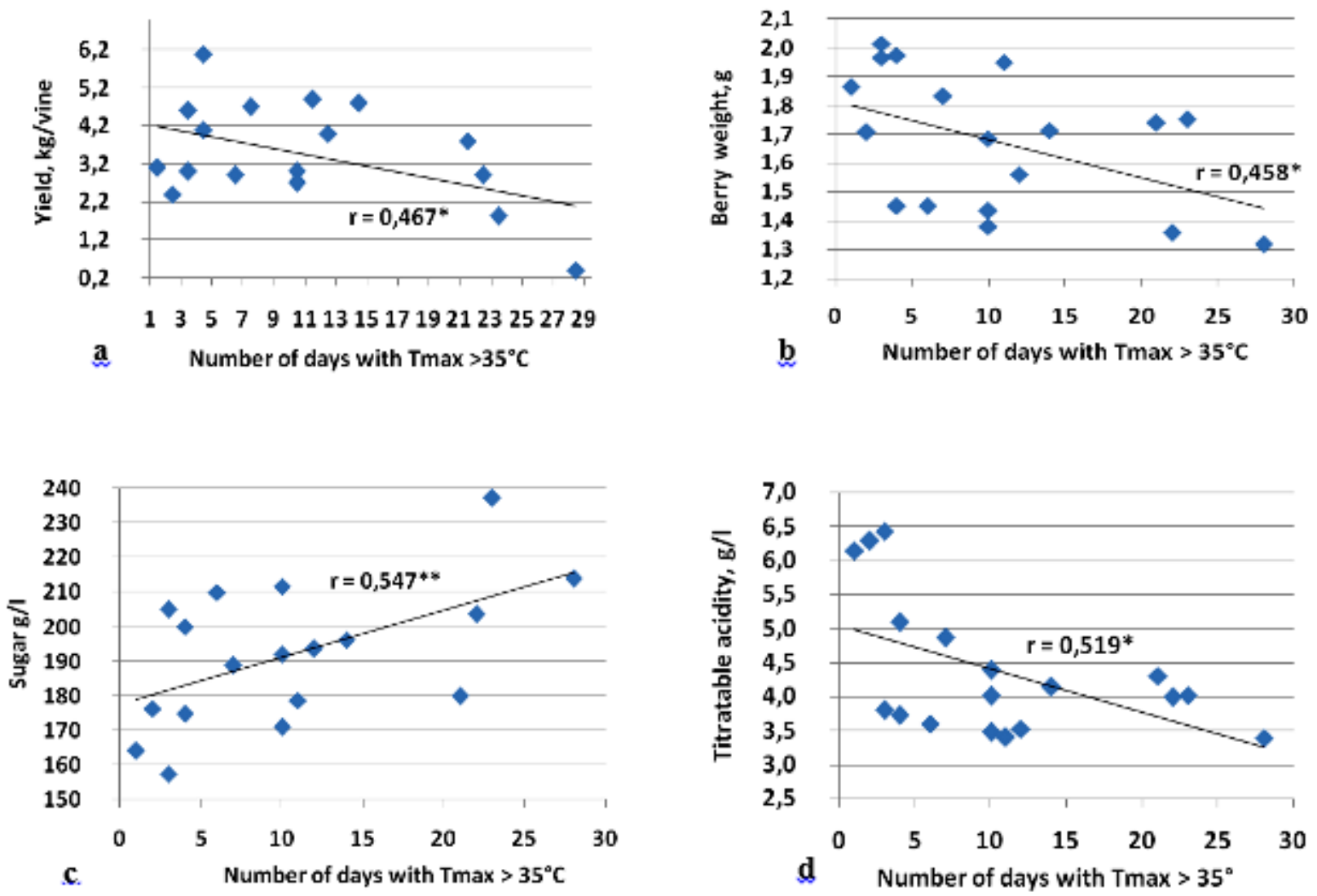

Fig. 5. Correlation between the number of days with $\mathrm{T}_{\text {max. }}>35^{\circ} \mathrm{C}$ and the average grape yield (a), berry weight (b), sugar accumulation (c) and titratable acidity (d) for ?Feteasca regala? cultivar (Bucharest-Baneasa, 19982015)

a.
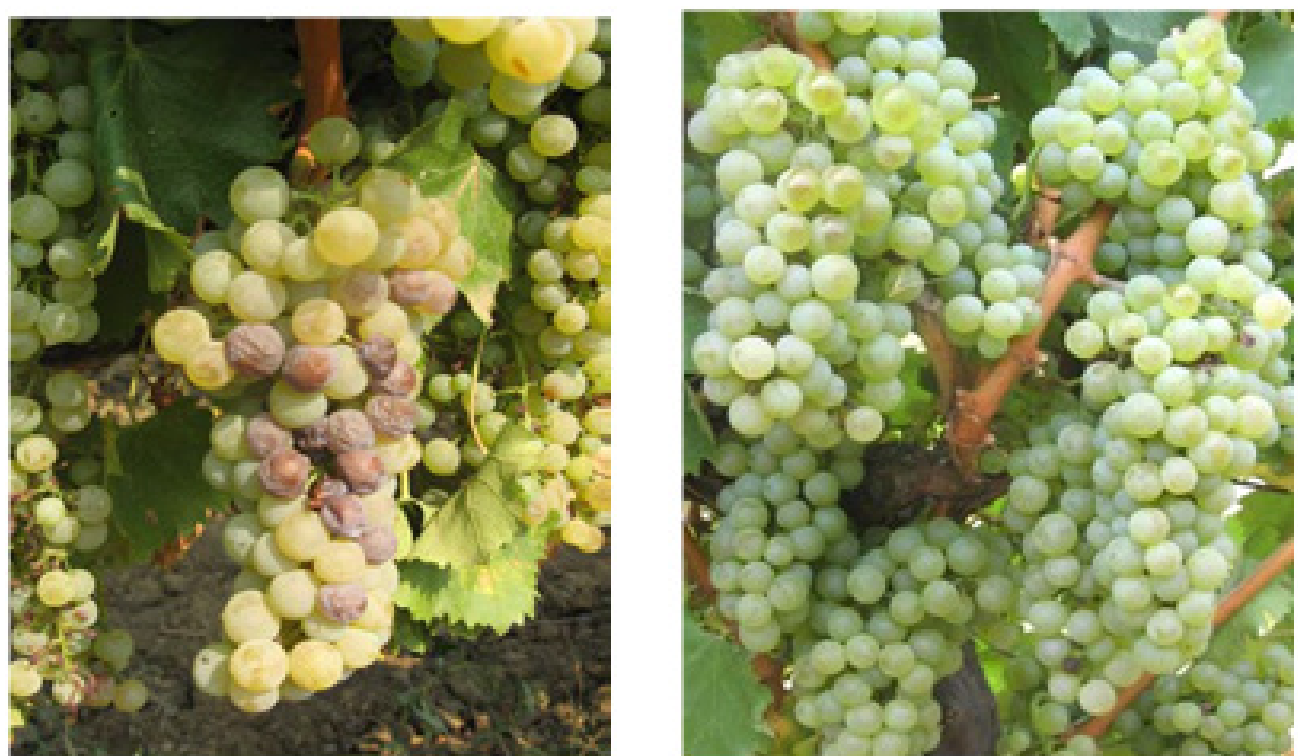

b.

Fig. 6. Detail with sunburned berries, caused by high temperature and solar radiation after defoliation, on the western side of the row (a), as compared to the normal aspect of the eastern side of the row (b), (BucharestBaneasa, 26.08.2007) 
Tab. 4. Precipitation deficiency recorded during summer (VI-VIII, mm) in 7 centers (1977-2015)

\begin{tabular}{|c|c|c|c|c|c|c|c|}
\hline Year & Craiova & Constanta & $\begin{array}{c}\text { Bucharest- } \\
\text { Baneasa }\end{array}$ & Timisoara & Cluj-Napoca & Oradea & Iasi \\
\hline 1977 & & & & & 169.2 & 140.0 & \\
\hline 1980 & 118.9 & & & 125.7 & & & \\
\hline 1981 & & & & & & & 107.8 \\
\hline 1983 & & & & 133.7 & 134.9 & & \\
\hline 1984 & 89.7 & & & 137.8 & 156.0 & & \\
\hline 1985 & & 77.1 & & & & & \\
\hline 1986 & & 62.1 & & & & & \\
\hline 1987 & 78.3 & & & & & & \\
\hline 1988 & 100.4 & 73.3 & & 136.6 & & & \\
\hline 1989 & & 75.0 & & & & & \\
\hline 1990 & 53.1 & 29.0 & 110.1 & & & & 154.2 \\
\hline 1991 & 93.4 & & & & & 54.1 & \\
\hline 1992 & 79.6 & 44.3 & 79.6 & & & 152.9 & \\
\hline 1993 & & & & 88.1 & & 59.1 & \\
\hline 1994 & & & & & 161.4 & 135.2 & \\
\hline 1995 & & 71.9 & & & & & \\
\hline 1996 & 67.0 & 44.4 & & & 165.4 & & \\
\hline 1998 & & & 120.9 & & & & \\
\hline 2000 & 77.7 & 82.8 & 67.2 & 74.8 & 154.5 & 71.1 & 140.5 \\
\hline 2001 & 109.7 & 63.2 & & & & & \\
\hline 2002 & & & & & 139.6 & & \\
\hline 2003 & 81.6 & 42.2 & 87.6 & & 140.0 & 89.2 & \\
\hline 2007 & & & & & & & 151.4 \\
\hline 2008 & & 79.4 & 94.5 & & & & 124.2 \\
\hline 2009 & & 54.0 & & & & & 153.8 \\
\hline 2012 & 48.3 & 45.0 & 77.6 & 134.8 & 173.2 & 120.0 & 70.4 \\
\hline 2013 & & & 142.4 & 123.3 & & 108.4 & \\
\hline 2014 & & & & & & & 140.5 \\
\hline 2015 & & & & & 167.7 & & 122.5 \\
\hline
\end{tabular}




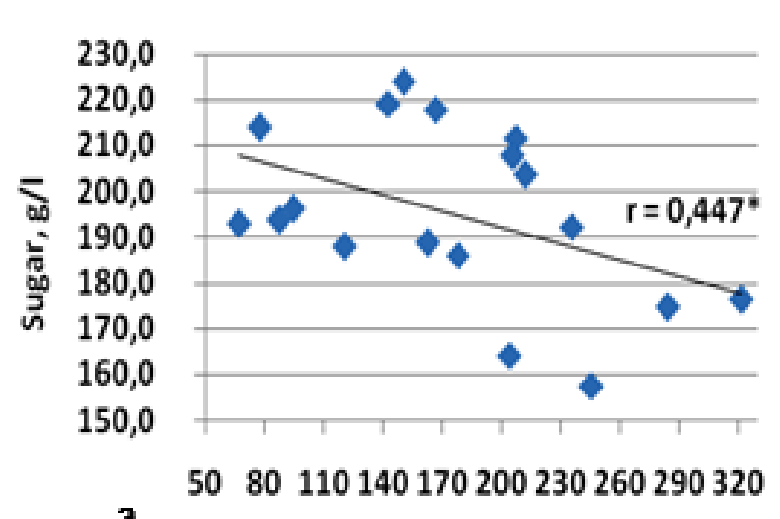

a

\section{Precipitation, $\mathrm{mm}$}

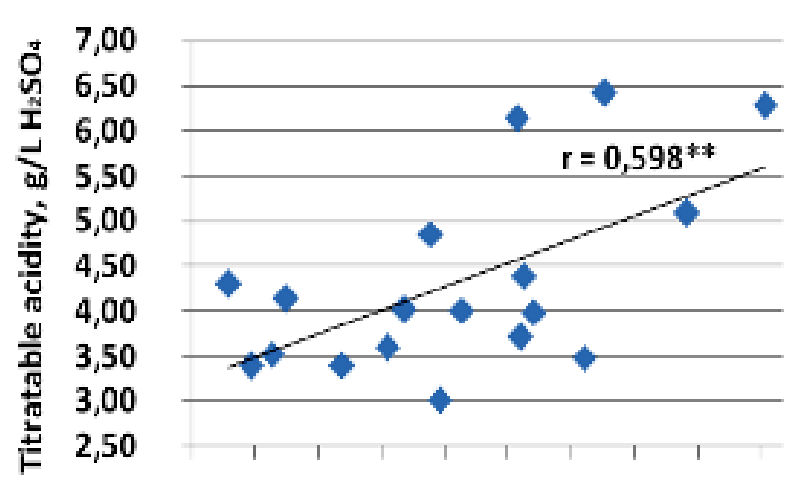

b
5080110140170200230260290320

Precipitation, $\mathrm{mm}$

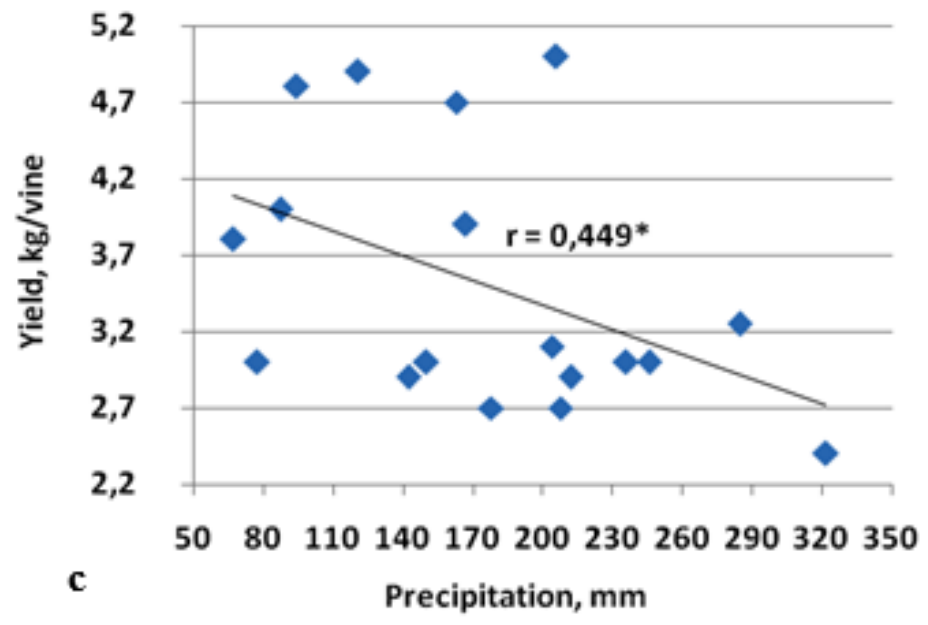

Fig. 7. Correlation between summer precipitations (VI-VIII) and sugar accumulation (a), titratable acidity (b) and grape yield (c), for ?Feteasca regala? cultivar (Bucharest-Baneasa, 1998-2015)

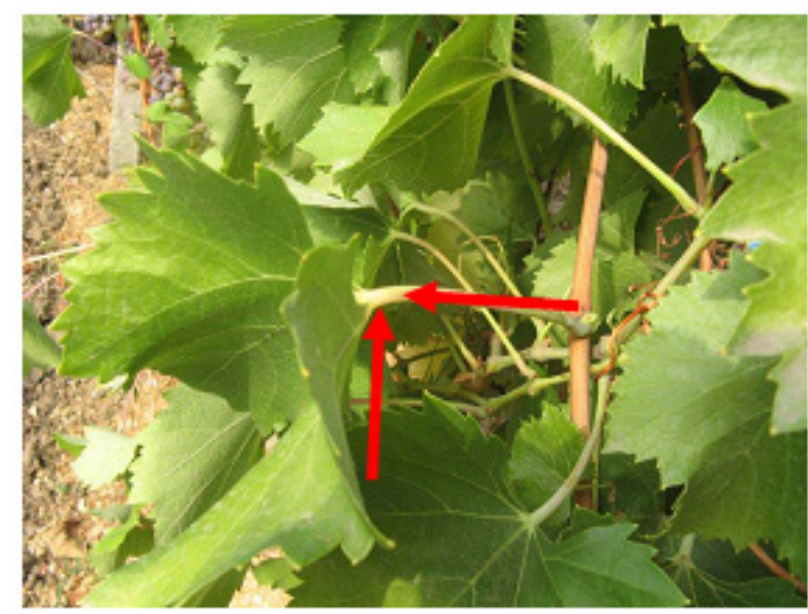

a

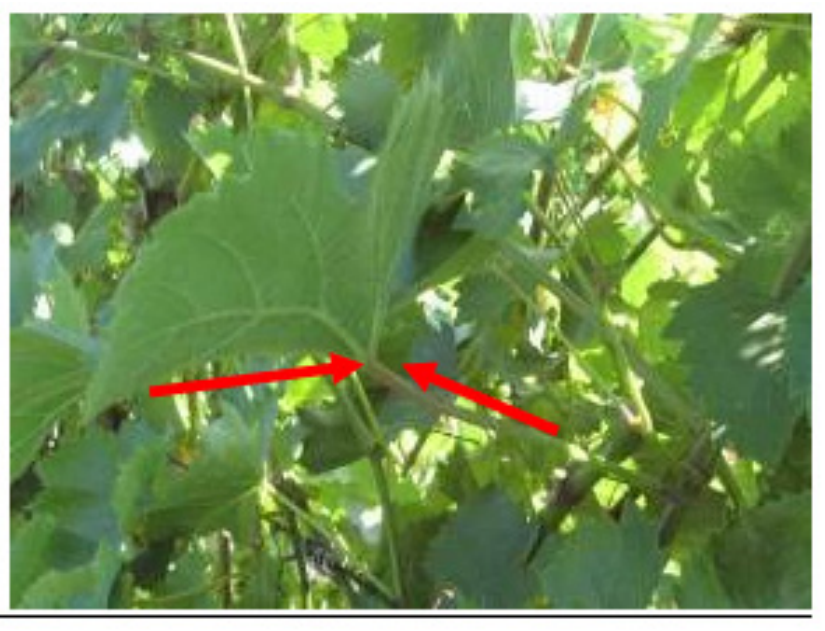

b

Fig. 8. Detail with the change induced by drought stress in the leaf blade insertion angle (26.08.2007) (a), as compared to the normal aspect (b), Bucharest-Baneasa 
Following accentuated water deficit and heat waves during the growing season in 2007, there were registered changes in the orientation of the leaves to reduce incidence of solar radiation, as an adaptation to water-stress conditions (Fig. 8). There is a decrease in the angle of insertion of the leaf lamina on the petiole and an orientation of the leaf tip towards the soil.

\section{CONCLUSION}

Frequently Romania temperate-continental climate is affected by heat waves in summer and cold waves in winter.

Analysis indicated that the increased frequency and intensity of winter frost would cause substantial production decrease.

Minimum temperatures were damaging the vines in winter period $\left(\mathrm{T}_{\min }<-20^{\circ} \mathrm{C}\right)$ are more common, especially in the northern parts of the country and in the plains in the south.

In recent decades, in all winegrowing regions of the country, it was significant increase was also found in the frequency and intensity of heat waves. Despite the heat waves, the accumulation of sugars in grapes increases and determinate a significant reduction of grape yield and titratable acidity, which lead to, unbalanced wines.

\section{REFERENCES}

1. Bieli M, Pfahl S, Wernli H (2015). A Lagrangian investigation of hot and cold temperature extremes in Europe. Quarterly Journal of the Royal Meteorological Society, 141:98-108.

2. Bois B, Moriondo M, Jones GV (2014). Thermal risk assessment for viticulture using monthly temperature data. Xth International Terroir Congress Tokaj Eger Hungary, 227-232.

3. Bucur GM, Dejeu L (2014). Influence of climate variability on growth, yield and quality of grapes in the south part of Romania. International Conference „Agriculture for Life, Life for Agriculture", Section 2, Horticulture, Bucharest, L VIII:133-138.

4. Dami IE, Ennahli S, Yi Z (2012). Assessment of winter injury in grape cultivars and pruning strategies following a freezing stress event. American Journal of Enology and Viticulture, 63 (1):106-111.

5. Dejeu L, Enescu M, Mereanu D, Ionescu A (2005). Frost resistance of some grape cultivars in the winter
2004/2005: Lucrări Științifice USAMVB, Seria B, XLVIII:313-318.

6. Dressler M, Oberhofer J (2015). Vineyard acreage simulations in consideration of climatic changes affecting Rhineland-Palatinate (RLP). BIO Web of Conferences. Proceedings of the 38th World Congress of Vine and Wine, 5 to 10 July 2015, Mainz - Federal Republic of Germany, 5.

7. Hill GK (2011). Frostrückblick 1956 bis 2010: Winterfrostschäden in Rheinhessen. Das Deutsche Weinmagazin, (3):26-28.

8. Iliescu M, Farago M, Comșa M, Ranca A, Boloș P, Babeș A (2009). Evaluation of the climate changes in Târnave and Murfatlar vineyards. Bulletin of University of Agricultural Sciences and Veterinary Medicine, Horticulture, vol. 66 (1): 662.

9. Irimia L, Patriche CV, Quénol H (2012). GIS-aided analysis of vineyards damaged by winter frosts. Case study: Cotnari vineyard (Romania). Cercetări Agronomice în Moldova, 45(4):75-88.

10. Lung ML, Pop N, Ciobanu F, Babeș A, Bunea C, Lazar S (2012). Environmental factors influence on quality of wine grape varieties in four different areas of culture. Bulletin of University of Agricultural Sciences and Veterinary Medicine Cluj-Napoca. Horticulture Vol 69(1): 219-227.

11. Mereanu D (2010). Researches regarding the influence of some technological links on the grapevine production quality enhancement. PhD Thesis, UASVM Bucharest.

12. Pascual I, Arrizabalaga M, Fortun T, Santesteban F, Oyarzun M, Hilbert G, Irigoyen JJ, Morales F (2016). Influence of elevated temperature on fruit yield and grape composition of thirteen Tempranillo grapevine accessions differing in cycle length. International Symposium: Sustainable grape and wine production in the context of climate change, Bordeaux-France, April 10-13.

13. Planchon O, Quénol H, Irimia L, Patriche C (2015). European cold wave during February 2012 and impacts in wine growing regions of Moldavia (Romania). Theoretical and Applied Climatology, 120(3/4): 469-478.

14. Quamme HA, Cannon AJ, Neilsen D, Caprio JM, Taylor WG (2010). The potential impact of climate change on the occurrence of winter freeze events in six fruit crops grown in the Okanagan Valley. Canadian Journal of Plant Science, 90(1):85-93.

15. Rayne S., Forest K., (2016). Rapidly changing climatic conditions for wine grape growing in the Okanagan Valley region of British Columbia, Canada. Science of the Total Environment, 556:169-1078.

16. Rotaru L, Irimia L, Mustea M, Petrea G (2010). The behaviour of some grapevine varieties for wine at low temperatures on 2009/2010 winter in vineyard area of Iasi. Lucrari Stiintifice, USAMV „Ion Ionescu de la Brad” Iasi, Seria Horticultura, 53(2):401-406. 